\section{HEIDRICH Balázs}

\section{VÁLTOZÓ IDŐK NYOMÁBAN -}

KÍSÉRLET A MAGYAR ÉS ROMÁN SZERVEZETIKULTÚRAVÁLTOZÁSOK ÖSSZEHASONLÍTÁSÁRA

A tanulmány célja, hogy megvizsgálja a termelố- és szolgáltatószervezetek kultúrájának sajátosságait döntốen észak-magyarországi és erdélyi mintán. Az összehasonlításhoz hat dimenziót használt a szerzó. A két minta között jelentôs különbségek tapasztalhatók. A magyar mintán sokkal meghatározóbban jelentkezett a szektoriális hovatartozás. Ez a különbség a termeló- és szolgáltatószervezetek között nem jelent meg élesen a román mintában. A szervezeti méret mindkét mintán jelentốs kultúrabefolyásoló tényezónek bizonyult. ${ }^{1}$ Kulcsszavak: szervezetikultúra-változás, termeló- és szolgáltatóvállalatok, paternalista vezetô, átalakuló kultúrák

A rendszerváltoztatás óta eltelt idôszakban több kísérlet is történt a szocialista rendszerból átalakuló vállalat A szerveztek keciule helyzetet mutatták be pillanatelvételszerüen (Branyicky, 1989, Mánás, 1989; Hormeister - Bauer, 1995, Simo - Davies, 1995; Jajjabka, 2002), az ellế nemzeti kulturális hátterú szervezetek együttmúködésének kihívá saival foglalkoztak (Child - Markóczy, 1993; Meschi Roger, 1994; Poór, 1995; Gaál - Szabó, 1996, Primecz - Soós, 2000), es a hazai szervezeteken belül kialakulo szubkultúrák jellemzőire fókuszáltak (Bokor, 2000). A szervezeti kultúrát jelentősen befolyásoló stratégia és alkalmazott módszereinek, valamint a tudatosság változásának rögzítésére is születtek részletes hazai tanulmányok (Balaton, 1994; Balaton, 2003a).

A nemzetközi összehasonlításra nagyon jó kiindulási alapot jelent és jelenthet a jövóben is a CLOBEfelmérés kelet-európai, valamint hazai tapasztalatainak folyamas publikálás (Bakacsi - Takás, 1997; Bakacsi, 1999; Bakacsi et a . 2002; Karáconyi, 2006; Toárniczky, 2006)

Jelen tanulmány kísérletet tesz a változás/változtatás folyamatának rögzítésére. Az empirikus tanulmán alapjául egy elméleti modell és az abból kialakítot kérdőív szolgált. Az itt felmért magyar szervezeti kultúra jegyek korábban publikációkban megtalálhatóak (Heidrich, 1997, Heidrich, 1999). A változások ismertetése ezekhez képest történt.

A felmérést elôször Magyarországon folytattuk le, kiemelten az észak-magyarországi régióban, mint a hogy a változ ét́s folya felok sút ben a valoz mási folya fellegván ben jeloriok no régiókat kerestün a környezó országokban (Románia - Kolozsvár, Szlovákia - Kassa, Ukrajna - Harkov) helyi társegyetemekkel való együttmuködésben. Ezek közül a romániai felmérés eredményei váltak statisztikailag összehasonlíthatóvá.

A tanulmányban először a modell és elméleti keretrendszerének ismertetése történik meg, majd a magyar felmérés primer adatainak feldolgozása, amit az összehasonlító elemzés követ. Az összehasonlítás jelenség szinten azonosítható szekunder tapasztalatait és a kultúraváltoztatás lehetséges irányait mutatja be a zárófejezet.

\section{Egy lehetséges}

\section{szervezetikultúra-változtatási model}

A szervezetikultúra-változtatás szakirodalmi feldolgozása és empirikus tapasztalatai alapján (Heidrich, 1999) egy modell készült, mely szintetizálni próbálja a kultúraváltoztatásra ható lehetséges tényezôket. Ezek hatóerejének intenzitása és annak mérése, megkülönböztetése azonban nem célja a munkának (1. ábra).
A szervezetikultúra-változtatás befolyásoló tényezók

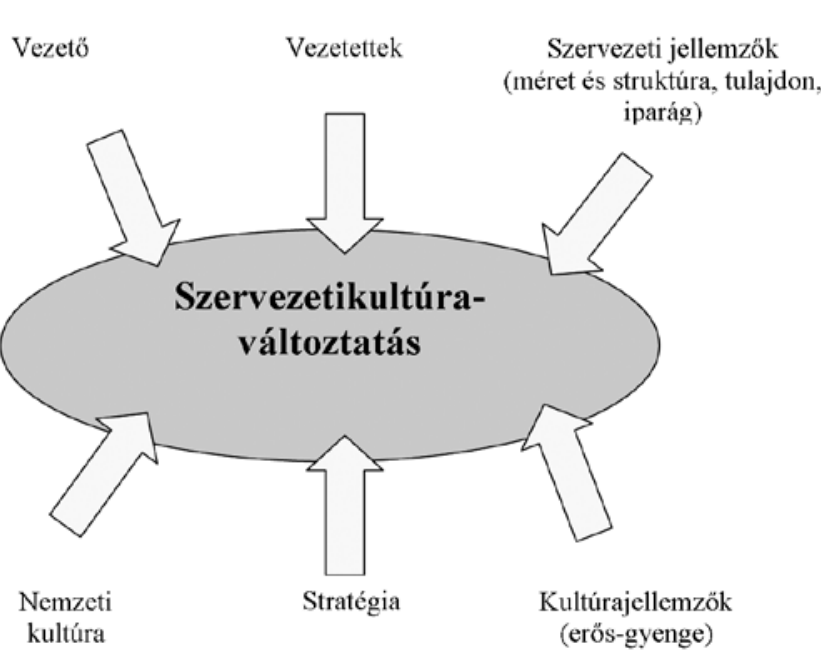

Vezetó

A vezetố hatása a kultúrára kiemelkedó jelentőségú. Az alapítók és vezetók példaképek vagy legalábbis viselkedési minták az alkalmazottak körében. Cselekedeteik és viselkedésük által naponta nyer igazolást és megerósítést a meghirdetett kultúra, és váti által vallott hiedelemmé (Schein, 1985).

Ide tartoznak azok az alkalmazottak számára is iránymutatónt szolgálo döntések, mint a juta

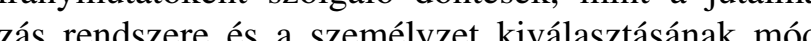

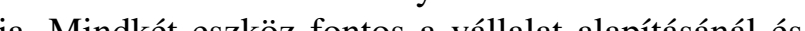
kultúrav́lteztán f́l is. Ezzo az eszozzôk az és a elíte viselkedesi m. Ezek az eszkozock az elóbb enát viselkedesi mintakhoz képest kozzvetve, de legalább olyan erôvel hatnak. Másfelól, míg viselkedési mintaként csak passzivan befolyásolja a kultúrát a vezető, itt aktív eszközökkel képes a maga elképzelései irányába terelni a normákat, közösen vallott értékeket. Itt is jelentős a személyes jellemző́k szerepe, melyeket akaratlanul is érvényesít a személyzet kiválasztásán (Nahavandi - Malekzadeh, 1993).

A vezetói döntéshozatal módja a kultúrafejlódés bármelyik szakaszában hosszan tartó hatással bír a szervezeti múködésre. A döntéshozatal módjai elvárés-

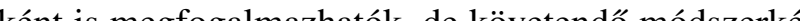
is beépïlnek. Fontośrgut jelzi, hogy ezek a vezeñ

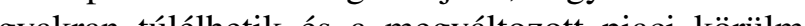
gyakran túlelietik és a megvâttozott piaci körülmé nyek között jelentenek segítő vagy sokszor hátrálta kapaszkodót a döntéshozatalban.

\section{Vezetettek}

Az alkalmazottak, mint a változásokat „elszenvedók” és végrehajtók, „lecserélhetetlenek”, ezért adotságként kezelendốk a kultúravâltoztatás kapcsán. Hosz- sú távon természetesen van esély a gondolkodásmód megváltoztatására - mint bármely kultúraváltás központi elemére -, rövid távon azonban ésszerúbb a rendelkezésre álló szervezeti tagságot és annak változási hajlandóságát felmérni. Természetes, hogy a változásra való hajlandóságot hosszú távon sem mutatók lecserélése indokolt lehet.

Az alkalmazottak mint humán eróforrások szintén megszabják a maguk szakképzettségével, képességeivel és motiválhatóságukkal, hogy milyen irányt vehet a változtatás, mi lehet az elérni kívánt kulturális modell.

\section{Szervezeti jellemzók}

A szervezeti kultúrák átalakulásának folyamatában jelentős szerepet játszanak a vállalat tulajdonviszonyai, a szervezeti struktúra és méret, valamint az adott iparág.

\section{Tulajdoni viszonyok}

A vállalat tulajdoni viszonyai sokszor jelentôs hatással vannak bármilyen változâsi folyamatra, ami igaz a kultúrára is. Magántulajdonban levő szervezetek gyakran sokkal gyorsabban döntenek a szükséges változtatásokról, és radikálisabban hajtják/hajtották végre azokat, mint állami tulajdonban levố társaik. Külön árnyalják a helyzetet a multinaciońlis tulajidoń cégek melyeḱ1 még több tényezóbefolyásolta a kúcek, toźcín toztatást. Sok helyen egy keszen kapott, más helyen kutút a (-iek tún) modellhez próbálták igazítani a kultúrát, ami veszélyes megközelítés, de sokak szerin az egyetlen járható út.

Szervezeti jellemzók

A szervezeti struktúra kölcsönös függóségben létezik a kulturaával. Bármelyik legcsekélyebb változtatása jelentós hatással lesz a másikra. Egy új struktúra kialakításakor megváltoznak a hierarchikus és hatalmi viszonyok, új szervezeti egységek szúnnek meg és alakulnak, és ami szintén nem lényegtelen, más emberek kerülnek kapcsolatba másokkal, mint addig. Ezek alapjaib ráz jaiban rázh ják megációt és jelenté szokásokat, jo jố Mindez az addig létezó kultúra feltétlen újragondolásá A menedzselését teszi szükségessé.

A kultúrát jelentôsen meghatározza a szerveze mérete. Nem minden körülmények között igaz, de általánosságban elmondható, hogy kevés vállalat tudja feloldani a méret és szervezeti rugalmasság közötti ellentétet. Kisebb méretú szervezetek esetén gyakoribb a rugalmas, az alkalmazottra jobban építő kultúra, mely nagyban támaszkodik az egyéni kreativitásra és döntéshozatali képességre. Ez a méret növekedésével fokoza- 
tosan elhalványul, és a szabályokhoz való ragaszkodás válik az egyik legfontosabb értékké, ami természetesen háttérbe szorítja az előbb említett jellemzóket.

\section{Iparág}

Az a piac, melyben a szervezet létezik, sok tekintetben behatárolja a kultúra megváltoztatására vonatkoz lehetőségeket. A turbulens gazdasági környezet, illetve a kevés vagy egyetlen szereplővel múködő piacok más szervezeti kultúrát validálnak, mint élet- és piacképest. Téves azonban az a sokak által osztott feltételezés is, hogy az iparág és az alkalmazott technológia determihogy az ip is és az alk alterm toztatására. Azonos iparágban múködő szervezetekn is tapasztalkatunk gyökeresen eltêr mindegyik lehet sikeres.

\section{Stratégia}

A szervezet stratégiája, a kultúra változtatásának irányát meghatározó tényezó lehet a már említe stratégia-struktúra-kultúra kölcsönös függósége miatt. A kultúraváltoztatást gyakorta a stratégiai változások egyik elemeként határozzák meg. Az biztos, hogy akárcsak a struktúra esetében, lehetetlenség elkülönülten kezelni a kultúrát a mindenkori stratégiától. Hiszen lehetetlenség elvárni a szervezet tagiaitól, hogy új cálorö kat kövessen a égi étékek es viselkedések menté A strategiara vonk a solja a „, hulturalis taka kilog alóla a szervezet. Ezért a legszerencsésebb bármilyen văltoztatási akció esetén tudatosan közösen kezeni e kettót, és nem késóbb elcsodálkozni egy „érthetetlenuil" kialakult kulturális problémán vagy stratégiával való inkonzisztencián.

\section{Nemzeti kultúra}

A szervezetalakitási és kultúraváltoztatási programok megvalósulásai kettoós hatás eredményeként jönnek létre. A felsôvezetés által jól megfogalmazott célok és cselekvési tervek hatnak felülról lefelé. Ezzel ellentétes irányban befolyásol a megvalósítás folyamán az

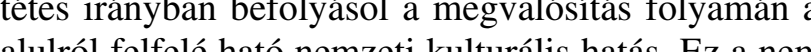
alulról felfelé hefó násol a megri zeti kulturális háltué az, amely péluál hazánkban esetenként akadályozhatja a változtatási programok megvalósulását.

Az egyéni attitúd azonban gyakran nem személyes ellenállás eredménye, hanem a korábbi szervezeti és a jelenleg is létező nemzeti kulturális háttér hatása. Ezéı érdemes minden vezetésnek több oldalról megvizsgálnia a változtatások során jelentkezố döntési és hatáskōri, kommunikációs és lojalitással összefüggő motivációs problémákat.

\section{szervezeti kultúra jellege}

Az erôs kultúrák és a szervezeti kultúra változásának látszólagos ellentmondása feloldható. Kialakíthatók olyan erốs szervezeti kultúrák, melyek egyik fó alkotóeleme a változásra való képesség. Amit fontos leszögezni, az erôs, illetve a gyenge kultúra nem jelent minőségi megkülönböztetést. A kérdés erősen szervezet- és környezetfüggó

A kérdôív a fenti modell feltételezései mentén a következő kérdésekre épül:

1. Vezetói személyiség: Az elsô kérdéscsoport abból az alapvetô feltevésbő́l indul ki, hogy a szervezeti kultúrát egyik leginkább befolyásoló tényezố a leader típusú felsővezetô. E gondolatrendszer mentén vizsgálja a fönök-beosztott kapcsolat adott szervezetben általánosan elfogadott normáit. Továbbá azonosítja a szervezetben elfogadott vezetói mintát is a szervezeti és saját csoportjához való lojalitás és érdekképviselet alapján.

2. Vezetettek: A második kérdéscsoport a vezetetti szintet helyezi fókuszba. Itt is megfigyelhetố a szervezetben általánosan elfogadott - ha úgy tetszik tipikus - beosztotti minta megfogalmazására való törekvés. Milyen vezetetti viselkedésforma eredmé-

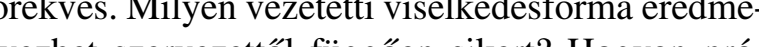

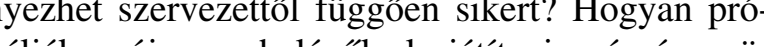
b́s Quinz vesuen Quinn versengó értékek modelljének tipológiájára epítve, mennyire a családias jelleg dominál, illetve mennyire elfogadott és transzparens a vezetettek között a belsô verseny léte?

. Stratégia és kultúra: A harmadik kérdéscsoport a szervezet stratégiájának megvalósulását, illetve a gazdasági és társadalmi környezet függóségét vizsgálja. A szervezet kultúrájába milyen mértékben épültek be a stratégiai tervezés módszerei és váltak napi szintú gyakorlattá? Szintén jelentős mértékben befolyásolja a stratégia és kultúra kölcsönös fügő̋ségét, hogy milyennek ítélik a szervezet tagjai a vátéget, hogy milyennek ítelik as

4truktúra és koordináció: A negyedik kérdéscsoport a koordinációs mechanizmusok múködését, a döntéshozatal jellegzetes formáit vizsgálja. Az alkalmazott technológia mint koordinációt befolyásoló tényező szerepe is azonosítandó. Fontos tényezó az információval való hivatalos és informális gazdálkodás mikéntje. Mennyire válik kultúraformáló hatalmi eszközzé az információ-visszatartás a szervezetben?

5. Szervezeti légkör: A következó kérdéskör témája a szervezeti légkör, az informális kapcsolatok szint- je és szerepe. Mennyire jellemzóek a munkahelyen túlnyúló kapcsolatok a szervezetre? Kifizetődô-e szervezeti lojalitás? Létezik-e kölcsönös elkötelezettség az egyén és a szervezet között? Érdemes-e mindkét félnek invesztálni a kapcsolatba? A vallot vállalati értékek köztudottak-e, és azokat a szervezet közvetíti-e tagjai felé?

6. Nemzeti kultúra: A nemzeti kulturális háttér mint szervezeti kultúrát befolyásoló tényezô az utolsó kérdéscsoportban szerepel. A kérdések az ismert kultúra-összehasonlító elméletek mentén vizsgálják a kultúra alpvető feltevéseit. Itt Trompenars, jak a kulté tivizterivion tivizmus/hndividualiznus, a féflas/nöles értékek dominanciája, partikuáris/univerzalista jellemzók mentén. A munkatempó, szabálykövetés, valamint az idôhöz való viszony lehetséges különbözőségeinek tárgyalása is sorra kerül.

A modell kérdései mentén a következő hipotézisek fogalmazhatók meg:

- H1: A termelő- és szolgáltatószervezetek szervezeti kultúrája eltér egymástól. Léteznek olyan vezetési, valamint belsố szervezeti múködést érintố jellemzốk, melyek a humán kapcsolatokban eltérést mutatnak. Az alkalmazott technológia jelentós mut hatással van a szab́n latok zát renczzery näkodése nagyobb szabálykovetess fetételez, mint a szolgáltatóké, ahol a humán interakciók sokasága nyitottabb rendszer eredményez.

H2: A szervezeti méret jelentôs befolyással bír a szervezeti kultúrára. Hatása azonban nem feltétlen azonos erősségú a modell különböző dimenziói mentén. Létezhetnek olyan dimenziók, melyek kissé vagy egyáltalán nem méretfüggő́ek. (A szervezeti méret fogalmát a kultúra esetében a létszám írja le legjobban, így a foglalkoztatottak számát választottuk mérési dimenzióként.)

- H3: A gazdasági és társadalmi környezet hatással van a szervezetek kultúrájára. Eltérố gazdasági és társadalmi fejlődési örökség és fejlődési pálya mentén eltérô kulturális jellemzók azonosíthatók.

\section{A felmérés struktúrája és módszertana}

A kutatási kérdốivet a Miskolci Egyetem Vezetéstudományi Intézetének programja ${ }^{2}$ keretében fejlesztettük ki (Szintay, 2006).

A szervezeti kultúrát vizsgáló kérdéscsoport komplex kérdốiv egy fejezetét képezte. Ez hat részbố allt, összesen 40 állítást tartalmazott, amelyeket egy
-7 skálán lehetett minősíteni aszerint, hogy a válaszdó mennyire ért egyet a kijelentéssel (1: nem értek gyet, 7: teljes mértékben egyetértek).

A magyar mintában 106, míg a románban 336 szervezetet elemeztek a kérdő́ív segítségével. Így összesen 442 vállalat kérdốive szerepelt értékelhetóként a mintánkban. A magyar mintában jól azonosítható volt a közszolgáltató szektor $10 \%$-ot meghaladó jelenléte (áram-, gáz-, vízszolgáltatók, kórházak), ami a feldolozás során igazolhatóan a szolgáltatóktól eltérố kultuális csoportként jelent meg.

A romániai mintában statisztikailag értelmezhetố ennyiségú közszolgáltatót nem sikerült azonosítani, jól körülírhatóan megjelent viszont a kereskedô cégek esoportja, amely nem bírt kulturálisan eltéró jellemzókkel a szolgáltatók általános csoportjához képest, így okat az összehasonlításban egyként kezeltük.

A kultúrafelméréseknél gyakori „szakértôii vélemény módszert" használtuk a kutatás során. Ezáltal az adott szervezetek kultúrájára nézve nem tehetünk megallapításokat, az egyes vállalatcsoport-típusokra viszon igen. A minta megoszlása az 1. táblázatban látható.

1. táblázat

A magyar és román mintában szerepló szervezetek iparági megoszlása

\begin{tabular}{|l|c|c|}
\hline Iparág/ország & Magyarország & Románia \\
\hline Termeló & 50 & 199 \\
\hline Szolgáltató́ & 44 & 72 \\
\hline Közszolgáltató & 12 & 0 \\
\hline Kereskedelem & 0 & 65 \\
\hline Összes & $\mathbf{1 0 6}$ & $\mathbf{3 3 6}$ \\
\hline
\end{tabular}

A magyar minta regionális megoszlása

2. ábra

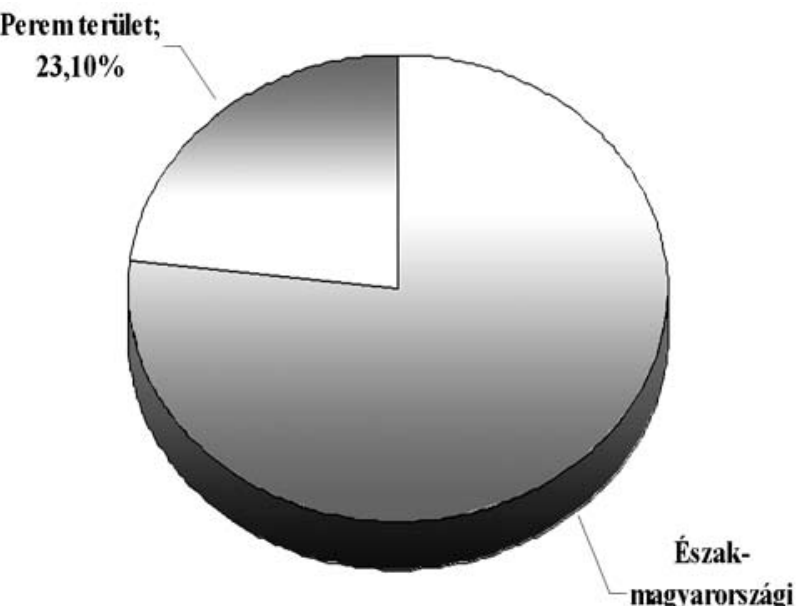

agarország

igió; $76,90 \%$ 
A román minta regionális megoszlása

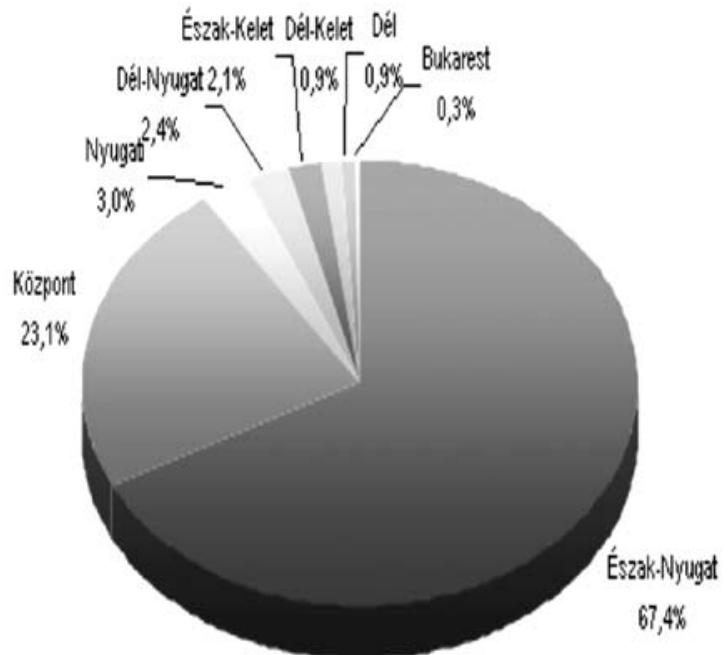

A minták földrajzi megoszlásánál fontos kiemelni, hogy nem reprezentalják az adott országok teljes területét, így kultúráaját sem. Az eredeti kérdoóives felmérésse összhangban és az alapvető hipotézis céljainak (ti. termelô- és szoloáltatószervezetek összehasonlítása) azonban meofelel, hogy Magyarorszáoon fóleg az észak-maban megfelel, hogy Mánán gyarországi, mig Romániaban az északnyugati területre (ti. Erdely) fokm

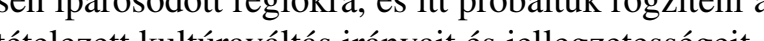
tételezett kultúraváltás irányait és jellegzetességeit. ábra.

\section{1. kérdéscsoport: A vezetố}

Az elsố kérdéscsoport a vezetố kultúrabefolyásoló hatását vizsgálta. A kérdésekre adott válaszok értéke 3,58 és 5,92 között mozgott. Mindkét szélsőérték közszolgáltatószektorban fordult elő. Az egész kérdéscsoport legmagasabb értékét ,a szervezetben sikeres vezetók szakmailag kompetensek, hatékonyak és erósen lojálisak a szervezethez” álításra a közszolgáltató szektor kapta.

A hat kérdés közül ötben a termelôvállalatok érték el a legalacsonyabb értéket, a vezetô stílusa itt a legkevésbé alkalmazottbarát. A termelővállalatoknál érezték legkevésbé igazságosnak, lojálisnak és feladatorientáltnak a vezetốt. Feltứnó, hogy a vezetô és alkalmazottak, valamint a vezetô és szervezet közötti lojalitás mértéke is itt volt a legalacsonyabb. A legmagasabb értékeket általában a közszolgáltatószervezeteknél kaptuk, kivéve a hatáskör és utasítás kérdését, ami a szolgáltatóvállalatoknál kapcsolódott leginkább a szakmai felkészültséghez.
A kérdéscsoport következetesen legmagasabb értékei a közszolgáltatószektorban születtek. Az átlagértékek alapján egy konzervatív, de a vezetettek által elismert vezetói kép követhetó nyomon a közszolgáltatóvállalatoknál, ahol a vezetói dimenzió szakmai és emberi megitélése is a legpozitivabb. Ettól jelentôsen elmarad a szolgáltatóvállalatoké, és még inkább a termelóké. A termelö́cégek a vezetó szakmai kompetencián alapuló hatáskörében érték el a legmagasabb átlagértéket, míg a közszolgáltatóknál a döntés hatalom és státus kérdése (4. ábra).

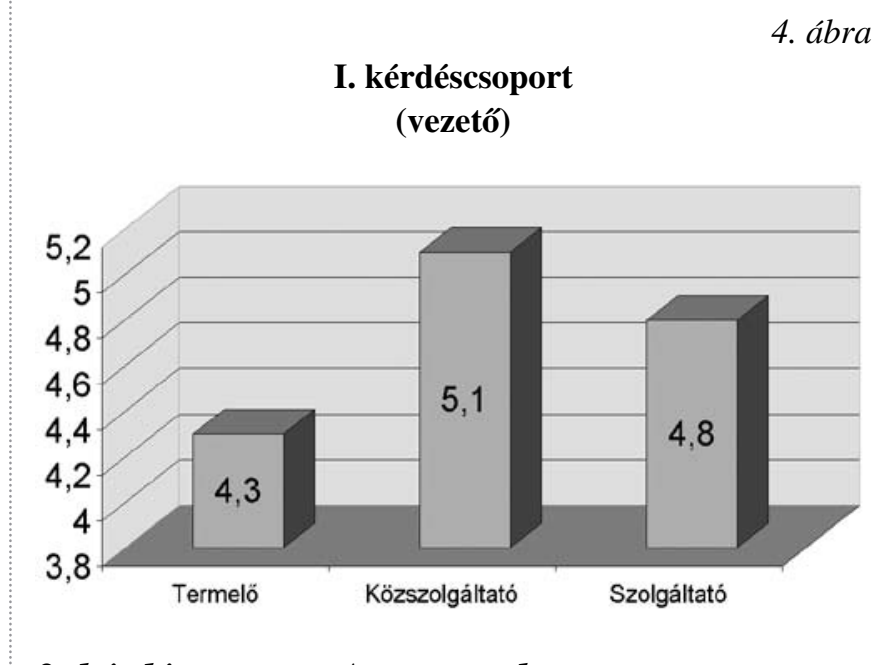

2. kérdéscsoport: A vezetettek

A második, vezetettekkel foglalkozó kérdéscsoport értékei meglehető́sen nagy eltérést mutattak, a szektoronkénti értékek 3,31 és 5,92 között mozogtak. A legmagasabb értéket a közszolgáltatószektor érte el a 2 . kérdés kapcsán, amely szerint „a jó beosztott belsóleg motivált, a feladatokban a legjobb tudását adja. Alapvetôen fontos számára saját fejlódése, szivesen tanul és fogad el segitséget”. Az elsố kérdésben, amely a beosztottak munkához való hozzáállását és szervezeti lojalitását vizsgálta, szintén a közszolgáltatók mutatták fel a legmagasabb értéket.

A legalacsonyabb értéket a termelővállalatok érték el, a 6. állításnál, mely szerint „, a szervezet egy nagyon barátságos hely, mint egy nagy család. Mindenki segít, támogatja a másikat”. Itt a közszolgáltatók átlaga sem mutat sokkal magasabb értéket.

A szolgáltatóvállalatoknál jelentkezett a legnagyobb versenyhelyzet, a belső teljesítmények mérésének és egyenlốtlenségének természetessége. A kérdéscsopor legalacsonyabb pontszámait a vezetettek megbecsülésérôl a termelővállalatok érték el, míg a szolgáltató- és a közszolgáltatószektor felváltva kapta a legmagasabb pontszámokat. Elóbbieknél az erôs versenyhelyzet az alapvetó érték, míg a közszolgáltatóknál a tradíciók és hagyományok átadása fontos (5. ábra).

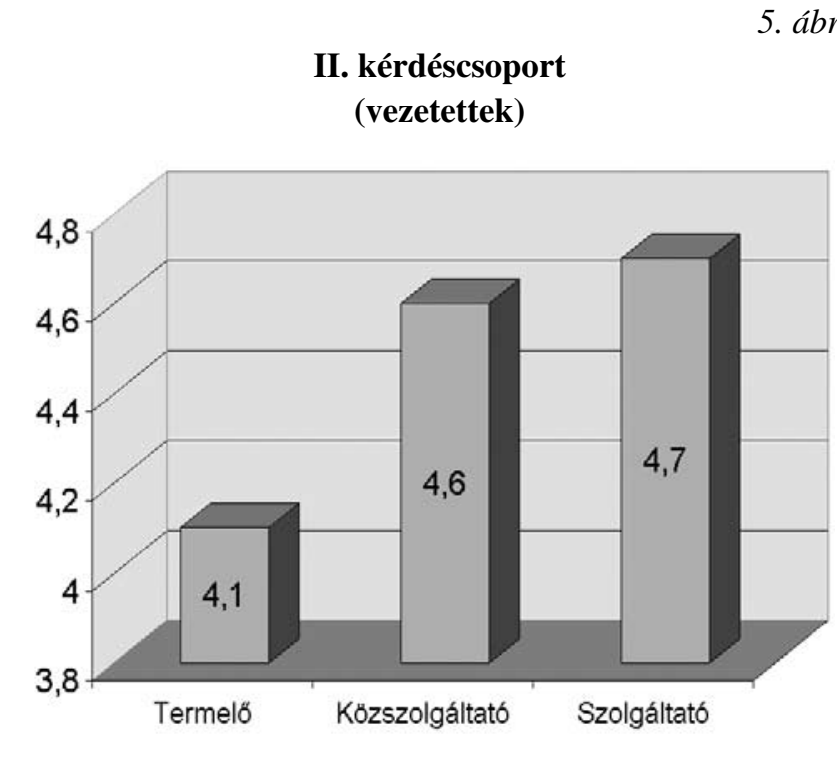

3. kérdéscsoport: Stratégia és kultúra

Ebben a kérdéscsoportban született az egész kérdőív legalacsonyabb átlagértéke, mégpedig a közszolgáltatószektorban, az 5. kérdésre, mely szerint a ,vállalati stratégia során jellemzó a piac-és versenytárselemzés". A szektor stratégiai tudatosság egyébkent is alacsony értékeket mutat a módszere szintjén. Érdekes módon ugyanez a szektor produkálta a legmagasabb pontszámokat a piaci és társadalm környezet megfelelóségét illetốen, míg ugyanezek az értékek a termelőszektorban voltak a legalacsonyabbak. Ebben a kérdéscsoportban a szolgáltatóvállalatok kapták rendre a legmagasabb átlagértéket a stratégiai tervezés eszközeinek használatában és a stratégia napi szintû megvalósitásában.

A környezetben bekövetkező változások elórejelezhetôsége a termelóknél érte el a legalacsonyabb értéket, míg a szolgáltatóknál a legmagasabbat (6. ábra).

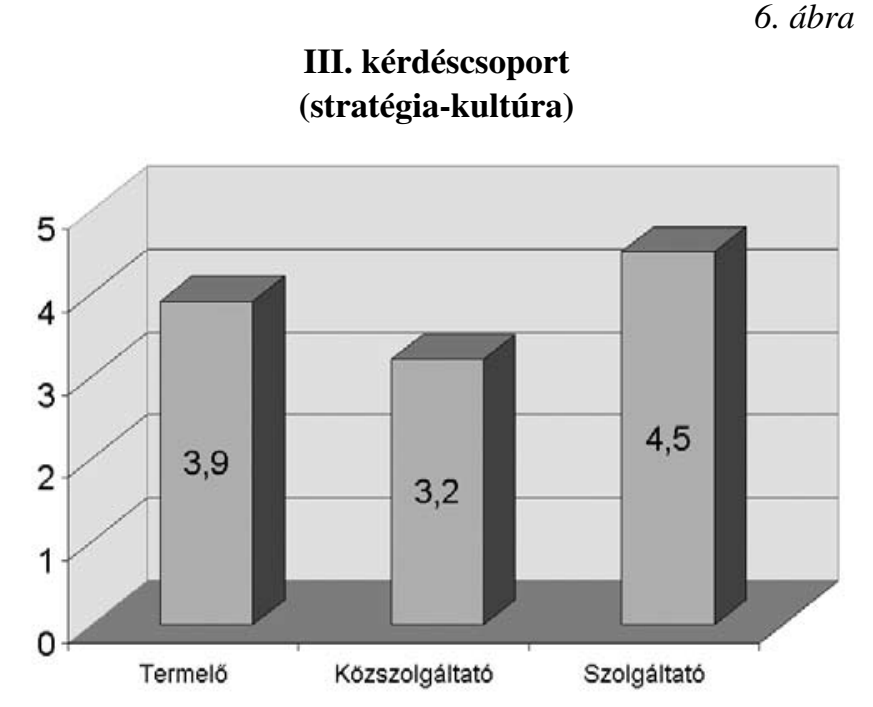

4. kérdéscsoport: Struktúra és koordináció

A kérdéscsoport hét kérdése/állítása közül ötben a termelővállalatok mutatták fel a legalacsonyabb értéket, így a döntések közös meghozatala és az információk megosztása kérdésében is.

Az információval való hatalmi gazdálkodás gyakorlata a közszolgáltatóknál a legerősebb. „,A kommunikáció többnyire szelektív, az emberek gyakran a kontroll eszközeként adnak vagy tartanak vissza információkat" kijelentéssel való egyetértés itt a legmagasabb. Az állítás fordított logikája miatt azonban ezt kifejezetten allís fo dét ló ebben a szektên êtelón ebben a szekt écechnológia által igényelt szabályozás szintjét és általában a szabályok fontosságát.

Ebben a kérdéscsoportban, amely a struktúra napi múködési megfelelốségét vizsgálja, a szolgáltatószervezetek kapták a legtöbb magas átlagértéket. Múködésük és a döntéshozatal demokratikusabb, mint a közszolgáltató, de fŏleg a termelőszektorban. Az információhoz jutás is könnyebb az alsóbb szinteken levőknek, mint a termelóknél (7. ábra).

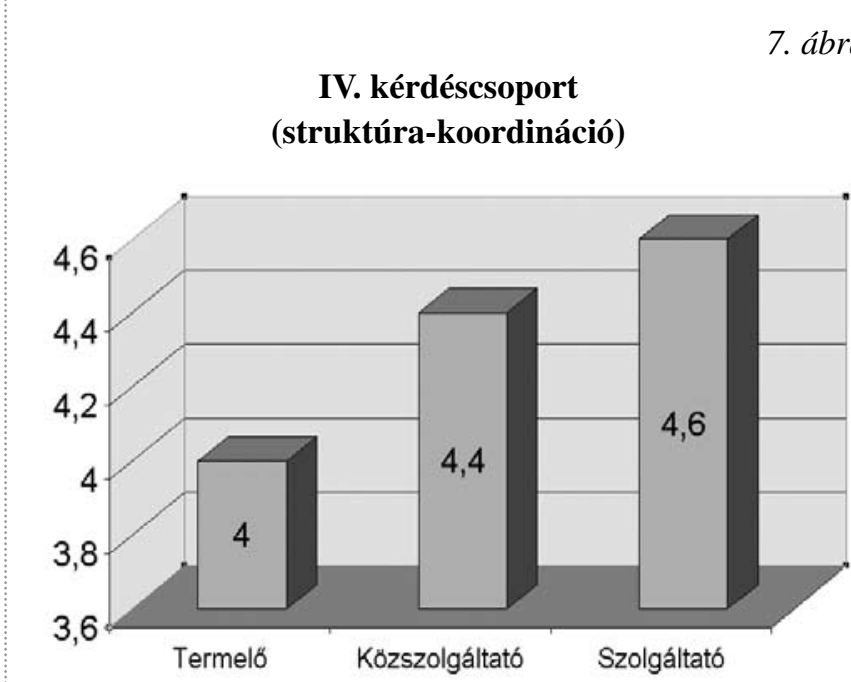

\section{5. kérdéscsoport: Szervezeti klíma}

Egyértelmúen megállapítható, hogy a szervezeti klíma, amely a szervezeti kultúra egyik felszíni, magatartásszintú manifesztálódása, a termelővállalatoknál barátságtalanabb, kevésbé alapul informális, a szervezeten túlmutató kapcsolatokon.

A legalacsonyabb pontszámot az egész mintára nézve a baráti, családias szervezeti jellemzók kapták, alátámasztva a vezetetti értékrendnél visszautasított családias jelleget. Szintén alacsony pontszámot kapott a kérdéscsoportban az elózőekkel szorosan összefüggố bizalom és baráti kapcsolatok értékelése.

A szervezeti értékek transzparenssé tétele viszont tudatosnak tűnik a mintában szerepló vállalatoknál, 
mert ez érte el a kérdéscsoport legmagasabb pontszámát. A szervezeti értékek hirdetésének keretet adó ceremóniák és rendezvények elfogadottsága viszont nagyon vegyes megítélésú, mely nagy eltérésekre enged következtetni.

A szervezeti klíma pontszámai rendre magasabbak a szolgáltató cégeknél, a baráti légkör és bizalom szintje itt szignifikánsan magasabb. A kultúra vezetôi szintû́, tudatos formálása is jellemzóbb a szolgáltatóknál a rendezvények és a nyíltan meghirdetett értékek tekintetében. Különösen szembetưnő a különbség a rendszeresen ismétlő́dő ünnepségek és ceremóniák kapcś́n. Az (lik alkäsebb a szolgáltatóknál ( 8 , ábra).

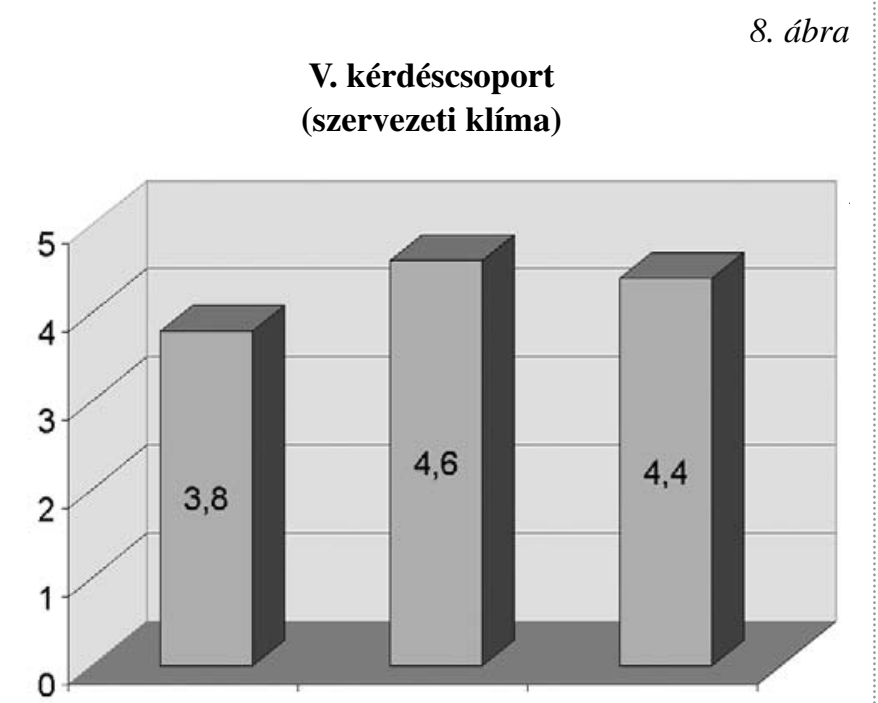

Termelä Közszolgáltató Szolgáltató

\section{6. kérdéscsoport: Nemzeti kultúra}

Az utolsó kérdéscsoport azt vizsgálta, hogy a nemzeti kulturális háttér mennyiben befolyásolja a munkahelyi viselkedést. A kérdéskör jellegéból adódóan itt jelentkeztek a legkisebb eltérések, hiszen itt már nem a szervezeti szint dominál, hanem a nemzeti, így érthető́bb a konvergencia. Az egyik legfontosabb kérdéskén jelentkező szabályok vs. szervezeti hatékonyság tekintetében a termelóvála stok mutatkoztak a legrugalm tetében a teńlón sabbro, nak. lgy nem meglepó a legmagasabb monokroniku átlagérték ugyanezen szektoban a határidók és tervek betartásával kapcsolatban. Megerôsitést kap a vezetó kérdéscsoport hatalmi kérdése, ismét a kôzszolgáltatóknál jelenik meg a pozícióból fakadó hatalom legerósebben, mint befolyásolási elem.

Erdekes ugyanezen ellentétpár megjelenése a férfias vs. feminin értékek mentén. A közszolgáltatószervezeteket vélték inkább férfidomináns szervezeteknek, míg a termelốknél jelent meg legkevésbé ez a különb- ségtétel. A munkahelyi innovációt a szolgáltatóvállalatoknál értékelik a legtöbbre és a legrugalmasabb (ti. polikronikus) munkatempó is itt a legjellemzóbb.

\section{A magyar felmérés}

szektoronkénti és méret alapján történó elemzésének következtetései

A szervezeti méret változásából adódó és a szektor szerinti hovatartozás szerinti kulturális dilemmák mentén a következő megállapításokat tehetjük:

A szektoronkénti vizsgálatok igazolták a hipotézist, miszerint jelentôs kïllönbségek mutatkoż a szolgétató-és jemö́nálla ség minden kérdéscsoportnál élesen megjelenik.

A termelôvállalatok kultúrájára - a szolgáltatókkal összehasonlítva - jellemző a vezetố kevésbé gondoskodó szerepe, az informális kapcsolatok alacsonyabb szintje, a szervezeti légkör barátságtalanabb jellege (nincs családi, egymást segitó érzés), valamint az információk hatalomféltésbốl való visszatartása.

- A szolgáltatóvállalatoknál jól tetten érhető a belsố versenyhelyzet, amely erős dolgozói motiváltságot okoz, de nem barátságtalan légkört. A szolgáltatószervezetek használnak leginkább környezetüket elemzó stratégiai módszereket, és náluk épült be a

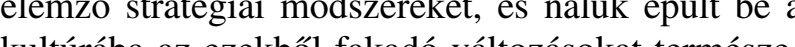
kulúa su az ezekól fakadó vál - Szignifikáns különbség jelentkezik a közszolgálta-
tószervezetek és a termelók, valamint a szolgáltatók között. Egy mindkettônél tradicionálisabb értékek mentén múködố kultúra rajzolódott ki. Ez még azt a kérdést is felveti, hogy a rendszerváltozás óta vajon lezajlott-e valódi kultúraváltozás ezen szervezeteknél? Egyrészt itt figyelhetốk meg több kérdéscsoportnál a legkedvezôbb eredmények (vezető kultúraformáló szerepe, szervezeti légkör), másrészt a jórészt monopol vagy kvázimonopol helyzetben levố szervezetek, noha nagyon megfelelónek tartják múködésükhöz a piaci és társadalmi környezetet, a stratégiai tervezés egyes módszerei teljesen hiányoznak tezin̈ eszköztr

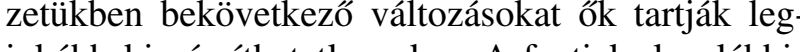
inkább kiszámithatatlannak... A fentiek, legalábbis hipotézis szintjén, felvetik az allam szerepébe vetet mindenhatoság hitének változatlanságát.

A szervezeti méret különbségei, melyek értelemszerúen a termelố- és a szolgáltatóvállalatokra korlátozódtak, a következő eredményeket mutatták:

A legbarátságtalanabb munkahelyek a nagyméretú termelővállalatok, ahol a mintára egyébkén jellemző gondoskodó vezetố sem jelenik meg.

- A nagyméretú szolgáltatószervezetek, a transzparens belsó verseny okán családiasnak nem nevevezetôi kezelése tudatos tevé kenységnek túnik.

\section{Román-magyar összehasonlítás}

A vezetö

A nemzeti kulturális összehasonlításban csak a második kérdésben nem mutatkozott jelentôs differencia (ti. feladatorientált vezetés). A kérdéscsoportban rendre magas bb román átlagpontsź́mok szillettek. A mare magasabb roún álagpontszáa szulettek. A magyanal is eốtebben jelent kep, valamint a vezetettekkel való kapcsolati szin foglalkozás igénye. A hatalmon alapuló hatáskör szintén dominált a hozzáértésen alapuló felett, a magyarnál is erősebb különbséggel.

Vezetôi kérdéscsoport magyar-román összehasonlítása

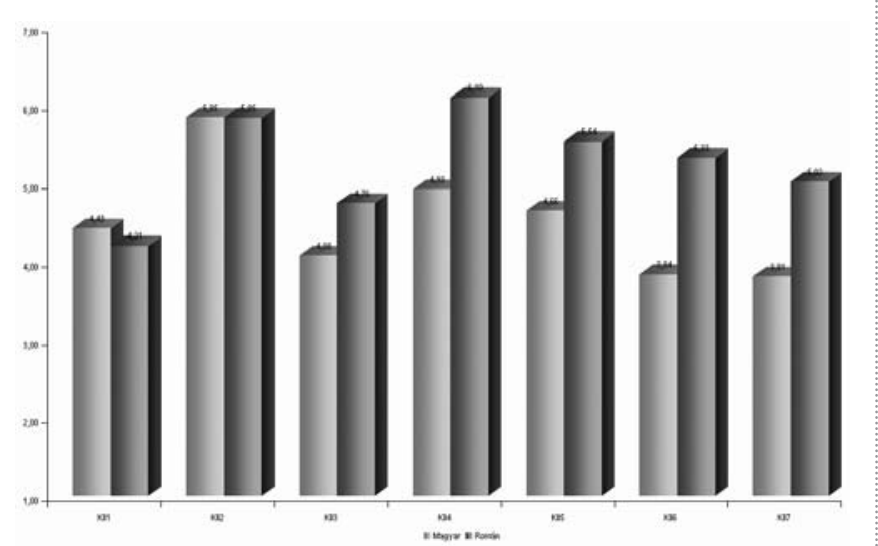

A vezetettek

A kulturális hovatartozás mentén a KII3-KII7 kérdések szignifikáns különbséget mutattak, rendre sokkal magasabb román értékekkel. Meglepó módon mind a családias, mind a versengó jellegú szervezetre magasabb átlagok szïlettek. A sikeresség zálogaként is sokkal inkább jelezték a szakmai kompetenciát és szervezeti lojalitást.

A legmagasabb átlagot a paternalista vezetô képét megerőssító személyes vezetối koordináción keresztül megvalósuló múködés kapta, míg a legalacsonyabbat az információ-visszatartás mint hatalmi eszköz.

\section{Stratégia és kultúra}

A stratégiai tudatosságot és azt a kultúra részének tekintô kérdéscsoport hét allítása közül òtben is szignifikánsan magasabb pontszám született a román mintāban. Mind a környezet érzékelésében, mind a kitúzött
Vezetetti kérdéscsoport magyar-román összehasonlítása

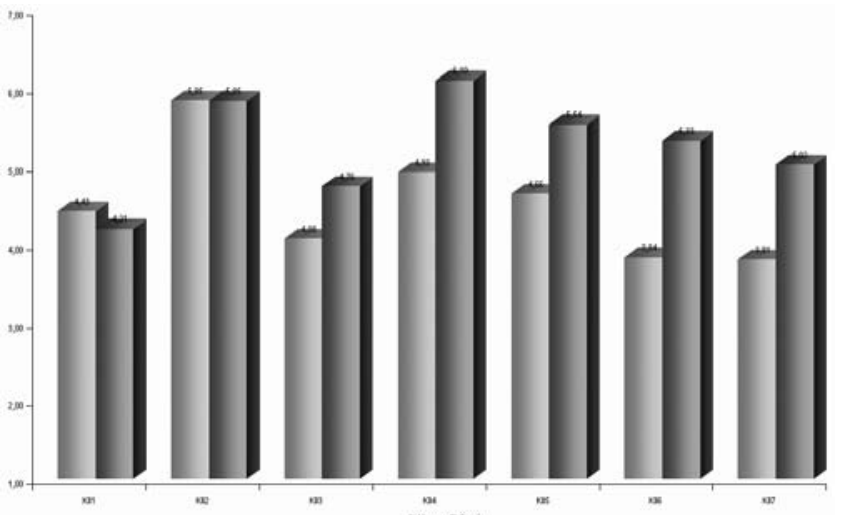

célok követésében magasabb szintú a stratégiai tudatosság. Kisebb mértékben, de a szervezeti tagok érintettsége is magasabb a stratégiaalkotásban.

Nem jelentős mértékben, de a magyar mintában a társadalmi környezetet megfelelóbbnek érezték a vállati múködóshez, valamint a vevóigény-elemzés is meghatározóbb volt a stratégia kialakításánál.

\section{Struktúra és koordináció}

A román mintában még a magyarnál is erôsebben jelent meg a felsővezető koordinálószerepe és információmegosztó, -visszatartó funkciója. Az információmegosztás mint hatalmi eszköz még erósebb kultúraelemként szerepelt a romaniai mintában. Érdekesség, hogy mindezek ellenére az információáramlást és döntéshozatalt a román mintában szabályozottabbnak érzékelték. A „kézi vezérlés” így, mint elfogadott kultúraelem, nyújt kapaszkodót a bizonytalan helyzetekben.

Szervezeti klíma magyar-román

11. ábra usszehasonlít́sa

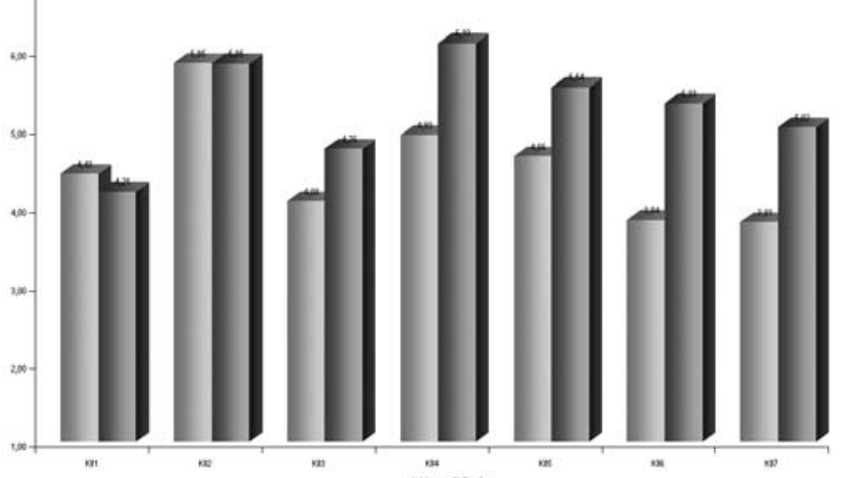




\section{Szervezeti klíma}

A román mintában a legmagasabb pontszámot a szervezeti értékek közös ismerete érte el. Meglepóen alacsony lett a szervezeti kultúrát erősítő események és a baráti légkör pontszáma.

A kultúra tudatos formálása a magyar mintában nagyobb, míg a bizalom, a szervezet barátságossága és dolgozók lojalitása a román mintában ért el szignifikánsan magasabb értéket.

\section{Nemzeti kultúra}

A társadalmi kultúra vonatkozásában felváltva szïlettek magasabb román, illetve magyar átlagpontszá-

Nemzeti kultúra kérdéscsoport román-magyar összehasonlítása

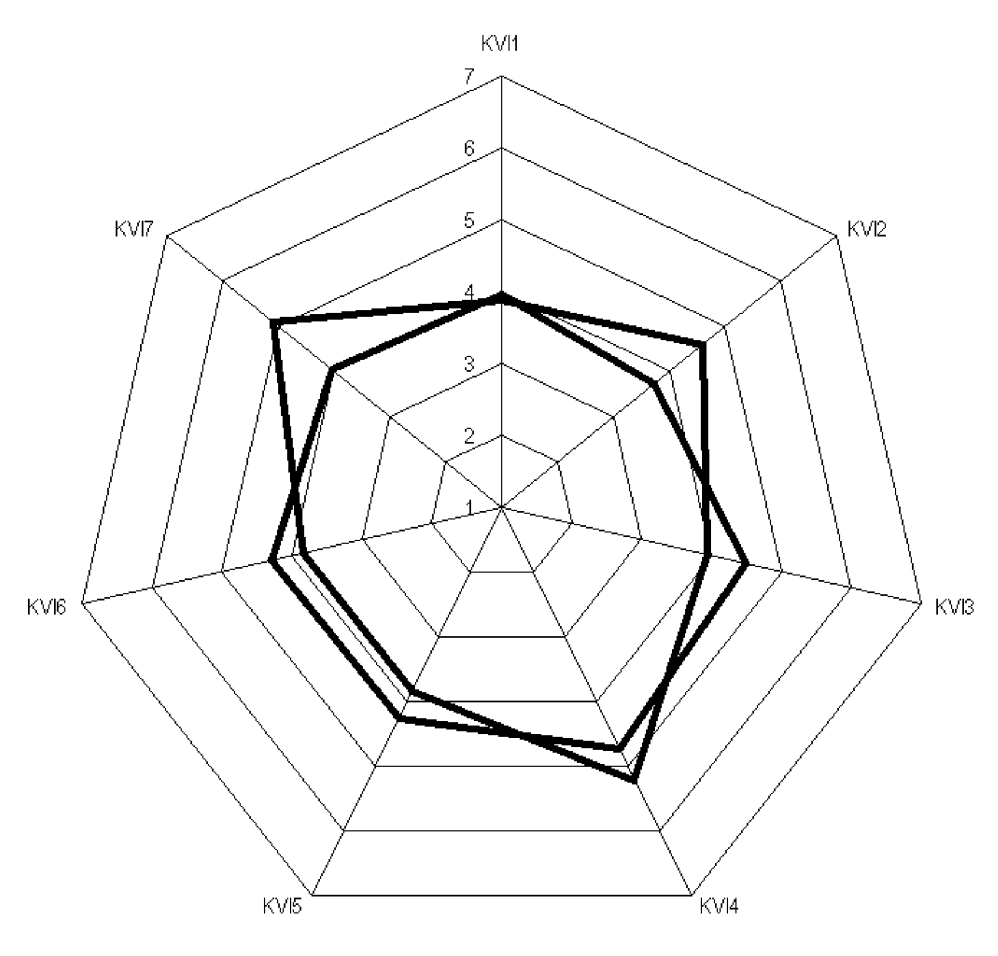

\section{Aaternalista vezetố mint általánosa}

\section{A fogadott vezetótípus}

A román mintában is egyértelmúen fellelhetố a patenalista vezeto alakja, még erósebben, mint a magyar szervezetnél. A szinte teljhatalmú, atyáskodó fónök határozott személyisége elvártként fogalmazódik meg a kerdőív kitöltő́inél. Az ilyen vezetó a vezetetteket nem partnerként kezeli, hanem gondoskodásra váró gyermekekként. Í ky kapcsolti szinten erös kölcsönös lojalitás

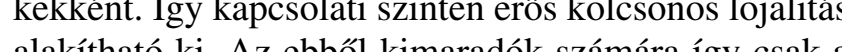
feladatok szintjén észlelhető autokratikus, kevésbé hu12. ábra mánus jellemzók maradnak

A paternalista vezetó alakja szektorfüggetlenként jelent meg a felmérésben. Megítélése nem tér el lényegesen a termelô-, illetve a szolgáltatószervezeteknél. A méret alapján történő elemzés tanulsága szerint megjelenése a kis- és középvállalatoknál gyakoribb. A paternalista vezetó jellemzője, hogy szervezeti szinten nem transzparens normák mentén irányít, hanem minden, lojalitási körébe tartozó vezetettel létezik eqy folyamatos játszmája”. Ez a játszma az ún. pszicholó.

Aromán minta erốs korrelációval igazolta vissza az atyáskodó vezetôt, mint szabályok felett álló, személyes irányítást használó személyt. Az információmegosztás szabályai is a kölcsönös kapcsolatok és feladatok függvényében értelmezhetók, nincs szervezeti múködésbe beépült rendszerük

A paternalista vezetôt, mint az egyik leginkább elfogadott típust, a magyar minta is igazolta. A múlt rendszer döntően autokratikus vezetối típusai közül ez a „túléló vezetố kép" a volt szocialista országokban. Míg a sa-

13. ábra

mok. Ezek az értékek a kérdéscsoport jellegéből adódóan nem minősító jellegúek (ti. a szervezet múködését pozitív vagy múködését pozitív vagy negatív módon befolyásolók), és gyakran ellentétes értékekre kérdeznek rá, így az abszolút értékük csak valamilyen irányú kilengést jelezhet.
A paternalista vezetó faktormodellje ját érdekei mentén múködó diktatórikus vezetố már kifejezetten elutastott, addig a hasonló feladatértelmezésú, de erốs kapcsolati szinttel bíró atyáskodó fónök továbbra is a kívánatosként megjelölt kategóriába került (13. ábra).

A paternalista vezetố megjelenése, érdekes módon. nem köthetố módon, nem kothetố szervezeti szignifiḱns különbség a kis- és közepes, illetve ez a vezetói típus inkább a kisebb szervezetekben volt tetten érhetó a primer adatok alapján. A szektoronkénti analízis szintén nem mutatott jelentős eltérést termelō- és szolgáltató szervezetek között, de ternista vezetó.

\section{Családias vs. versengö}

\section{szervezetek}

A román mintában faktorelemzés jól igazolta a szervezetek verseng jellegét. A versenyt a felmérés szerint ugyanúgy motiválja a teljesítmények

feladatalapú összehasonlítása, mint a kapcsolati szintú hatalom megszerzése.

Meglepó módon kifejezetten családiasként is értelmezték szervezeteiket a román minta kitöttói mig negatív kapcsolat nem volt kimutatható a kérdéspárok között. Ez azt az ideálisnak túnó állapotot feltételezi, hogy a belsô, egyének közötti szervezeti verseny a vállalatok szervezeti szintú, külsó versenyképességére is jótékony hatással van. Másfelól a Trompenaars és Hampden -Turner által is értelmezett, ellenpóluskén létezó értékek egymás mellett élését igazolja.

A szervezetek családias jellegét erôsítô kérdések lom és a munkív kapcsolatot találtunk, amelyben a bizamegjelentek. nagyméretú szervezetek között. Ezzel együtt is, szolgáltatószervezetekre kevésbé volt jellemzö a pa-

A versenygố szervezet faktormodellj

14. ábra

KII3

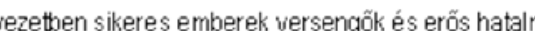
készztéśssel rendelkeznek.

A szervezet versengố beállitottságú. Mindenki a feladatára koncentrál és az alapián itílteteik meg.

Ebben a társadalomban a térfaknak van nagyobb esélye magasabb pozicióba kerüri

A családias szervezet faktormodellje

5. ábra

\section{VEZETÉSTUDOMÁNY}

A szervezeti kultúra változási folyamatában ez egy öztes állapotot feltételez. Míg a magyar mintában a családias jelleg már nem mutatható ki ilyen erôsen, addig a két, látszólag ellentétes érték jól megfér egymás mellett a románban. Különösen a termelö-, de a ta múlt öröḱf szervezet tuda és gondoskodó szervezet üközk meg a vallott értékek szintién már múk

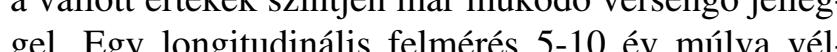
hetően longitudinális felmérés 5-10 év múva velhetôen már a múködő értékeknél is inkább a verseny értékeit erősítené meg, a családias értékek elhalványulásával (14. ábra)

A versengés tekintetében méret alapján nem lehetett szignifikáns különbséget kimutatni, de a vállalat

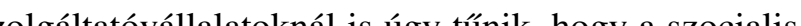


méretének növekedésével egyre versengóbbé váltak szervezetek.

Tevékenység szerint nincs szignifikáns kapcsola és tendencia sem mutatható ki, vagyis a versengés nem iparágfüggő́.

Ennél a kérdéskörnél a nemzeti kulturális háttér és a szervezeti kultúra között létezó kapcsolatot sikerül igazolni, a társadalom férfias jellegét igazoló kérdéssel. A versengést, mint jellegzetesen maszkulin értéket, kapcsolat köti a szervezeti szintú versenyhez (15. ábra).

Az értékpár ellentétes pólusán, a családias jellegnél elmondható, hogy szignifikánsan családiasabbak az 1-49 fốt foglalkoztató szervezetek, és minél nagyobb a szervezet, annál kevésbé családias. A szervezet tevékenységi köre (ti. termelő vagy szolgáltató) viszon sem kapcsolat, sem tendencia szintjén nem jelent me mint befolyásoló tényező.

A szervezeti kultúra informális építése megjelenik mint a családias jelleget erősító tényező, csakúgy, mint a magyar mintából hiányzó szervezeti szintú bizalom. Ez is azokat a feltételezéseket erősíti, hogy a román minta esetében a ,jó’-ként értékelt kultúraelemek nem biztos, hogy tudatos vezetói kultúraformáló tevékenység eredményei.

\section{Összegzés}

A tanulmány célja termeló- és szolgáltatószervezetek kulturális sajátosságainak és változási folyamatainak meghatározása volt, egy döntốen észak-magyarorszá gi és erdélyi központú román mintán. Hat kulturál dimenzió mentén történt a szervezetek összehasonlitása.

A román és a magyar szervezeti kultúra szinte minden kultúraelem mentén szignifikánsan különbözik egymástól.

Az empirikus felmérés tapasztalatai alapján megállapítható, hogy jelentôs különbségek talâhhatók két mintában a kulturális háttér alapjân. A magya tató) mint kultúrabefolyásoló tényezô jelent meg. A szolgáltatószervezetek szervezeti kultúrája jelentôsen szolgáltatószervezetek szervezeti kultúrája jelentôsen eltér a termelő vállalatokétól. Ez a külonbség kevésbé volt kimutatható a román mintán. A létszám szerint kzervezeti méretet viszont mindkét mintában jefolyásoló tényezóként azonosítottuk.

Aultúrabefolyásoló tényezóként azonosítottuk.
A felmérés szekunder elemzése során megállapítA felmérés szekunder elemzése során megállapitvezetối kép, ami a múlt rendszer puhább kezú, ember kapcsolatok mentén múködő vezetôi típusának túlélèsét mutatja.
A két mintában eltérő szervezeti kulturális fejlődési sajátosságokat fedeztünk fel. Míg a magyar mintában már elhalt a szocialista vállalat gondoskodó szerepe (kivéve a közszolgáltatókat!), és a vállalaton belüli jó informális kapcsolatok sem voltak jellemzőek, addig a román mintán egymással ellentétesnek túnő értékek (ti. családias múködés vs. versengés) egyszerre voltak megfigyelhetôek. Ez a különbség felveti a gazdaságitársadalmi háttérbốl adódó eltérố fejlốdési szint vagy pálya lehetôségét. A romániai kultúraeredmények alapján vélelmezhetố, hogy a szervezetikultúra-változtatás eltéró fózín retú ipa tên év és a felmérés longitudinális kiterjesztése azzány eve es a felmérés longitudinális kiterjesztése azonban

\section{Lábjegyzet}

A szerző ezúton mond köszönetet dr. Berényi Lászlónak (Miskolci Egyetem) a magyar és Molnár Lászlónak (Miskolci Egyetem) a román minta statisztikai feldolgozásában nyújtott segítségért. Szintén szeretnék köszzönetet mondani a kolozsvári Babes-Bolyai Egyetem Közgazdaságtudományi Karának, prof. Dumitru Matis dékannnak, prof. Vincze Márianak es Alt Mónika Anitának, az OTKA kérdóíí romániai lebonyolitásában nyújtott segítségért. "A stratégiai irányitás hatékonysááát befolyásoló tényezóḱk komp-

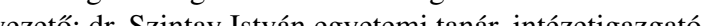

\section{Felhasznált irodalom}

Bakacsi, Gy. - Takács, S. (1997): Organisational and Societal Culture in the Transition Period in Hungary, 13th EGOS Colloquium, Changes in Organisational Cultures in Parallel with Environmental Changes)

Bakacsi, Gy. (1999): The Pendulum Effect: Culture, Transition, Learning, in: The Management and Organisation of Firm in the Global Context (Ed. Makó, Cs. - Warhurst, C.).; Institute of Management Education, University of Gödöllő and the Department of Management and Organisation, Budapest University of Economic Sciences (ISBN 9635515 0946), p. 111-118.

Bakacsi Gy. - Takács, S. - Karácsonyi, A. - Imrek, V. (2002): Eastern European Cluster: tradition and transition, Jour nal of World Business, 37(1), p. 69-80.

Balaton $K$. (1994): Vállalati stratégiai magatartás az átmenet idốszakában (1990-1994), Vezetéstudomány, No. 9

Balaton K. (2003a): A Magyarországon múködố vállalatok stratégiái - Kihívások és lehetőségek az átalakulási idószak végén (2002-ben), Vezetéstudomány, No. 1, p. 2-12. Balaton K. (2003b): Changing patterns of leadership during transformation period in Hungary, Journal for Eas European Management Studies, No. 4, p. 335-345.

Bokor A. (2000): Szervezeti kultúra és tudásintegráció: a termékfejlesztés problémája, PhD-értekezés, Budapesti Közgazdaságtudományi és Allamigazgatási Egyeten.
Branyiczki I. (1989): Szervezeti kultúrák empirikus vizsgálata, Közgazdasági Szemle, No. 1

(1993): Host-Country Managerial ehaviour and Learning in Chinese and Hungarian Joint entures, Jounnal or Mangenties, J

Gaál Z. - Szabo L-Lukacs E. (1996): Egy empirikus vizsg lat tapasztalatairol - ny

Hall, E.T. - Hall, M.R (198)
Differences, Intercultural Press

Hampden-Turner, C. - Trompenaars, F. (2000): Building Cross-Cultural Competence: How to create wealth from conflicting values?, Wiley\&Sons

Heidrich, B. (1997): A vállalati kultúra magyar sajátossága iról, Vezetéstudomány, No. 4.

Heidrich, B. (1999): The Change Of Organizational Culture In Transition Period In Hungary - Ph.D. dissertation University of Miskolc

Heidrich, B. (2002): A Possible Modelfor Cultural Changes in Organizations. AStudy Based on Hungarian Experiences Acta Oeconomica Cassoviensia N6. Ekonomick univerzita v Bratislave Podnikovohospodárska fakulta v Kosiciach. Kosice, p. 79-93.

Heidrich B. (2005): What Difference Does it Make? On the Characteristics of Cultural Changes in Differen Sectors in Northern-Hungary, In: Current Issues in Change Management: Challenges and Organisation Responses. (Ed. Farkas, F) Pécsi Tudományegyeten Közgazdaságtudományi Kar, Pécs, p. 51-59.

B. (2006): On the Differences Between Service and Production Cultures, Ekonomické Rozhl'ady. Ekonomická Univerzita v Bratislave. No. 3. p. 278289.

Heidrich, B. (2007): Two Sides of the Coin? Service, Production and National Culture as Decisive Factor on Organizational Culture: a Hungarian-Romanian Comparison, ISPIM-Asia Conference. Delhi, Ind 2007 Jan, p. 6-10

Heidrich, B. - Deak, Cs. (2007): Differences in Similarities: Service, Production and National Culture as Decisive Factors on Organizational Culture: A HungarianBeyond Waltz- Dances of Individuals and Organization
Hofmeister Á. - Bauer A. (1995): A magyar marketingvezetók helye a nemzetközi kulturális térképen - Positioning Hungarian Managers on the World Cultural Map, Vezetéstudomány, No. 6

Hofstede, G. (1995): Cultures Consequences: International Differences in Work-Related Values, Sage Publ. Beverly Hills, CA

Jarjabka Á. (2002): A magyar nemzeti-szervezeti kultúra változásának vizsgálata. PhD-disszertáció; Pécsi Tudományegyetem

Karácsonyi A. (2006): Szervezetikultúra-típusok a magyar vállalatok körében, Vezetéstudomány, különszám

Máriás, A. (1989): A vezetói emberkép és a vezetési stílus: Közgazdasági Szemle, No. 1

Keschi, P.X. - Roger, A. (1994): Cultural Context and Social Effectiveness in International Joint Ventures, Management International Review, vol. 34, No. 3

Cuvandi, A. - Malekzadeh, A.R (1993): Organizational Culture th The Management Or Mergers, Quorum Books zetési kultúrákban, Vezetéstudomány, No. 9

Primecz, H. - Soós, Á. (2000): Kulturális különbségek és kultúrák közötti együttmúködés vizsgálata egy Magyarországon múködó multinacionális es egy magyar vállalatnal kismins, tudomány, No. 6

chein, E.H. (1985): Organizational Culture and Leadership, Jossey-Bass, San Francisco

mon, L. - Davies, G. (1995): Cultural, Social and Organizational Transitions: The Consequences For The Hungarian Manager, Journal of Management Development ors. (2006). ERM alapú étécés az eszak-nagyarországi regio vallalkozásainak mintajan, Vezetéstudo-

mány, különszám
oárniczky, A. (2006): A szervezeti kultúra mérési kultúrája: kérdốiv tipológia és kulcsdimenziók, Vezetéstudomány, különszám

Trompenaars, F. (1993): Riding The Waves of Culture, The Economist Books

Cikk beérkezett: 2008. 10. hó

Lektori vélemény alapján véglegesítve: 2009. 1. hó
VEZETÉSTUDOMÁNY
VEZETÉSTUDOMÁNY 